${ }^{3}$ Mitcheil, D. S., Hydrobiologia, 34, 448 (1969)

${ }^{4}$ Leentvaar, P., in Man-Made Lakes (edit. by Lowe McConnell, R. H.), 33 (Academic Press, London and New York, 1966).

5 Little, E. C. S., in Man-Made Lakes (edit. by Lowe McConnell,

R. H.), 85 (Academic Press, London and New York, 1966).

${ }^{6}$ Jackson, P. B. N., Intern. Un. Conserv. Nat. Nat. Resour., 9th Tech. Meeting (1963).

7 Anon, Nature, 220, 957 (1968).

${ }^{8}$ Imevbore, A. M. A., Biol. Conserv. (in the press).

9 Worthington, E. B., in Man-Made Lakes (edit. by Lowe McConnell, R. H.), 3 (Academic Press, London and New York, 1966).

10 Imevbore, A. M. A., in Lake Kainji-Lacustrine Studies, 1 (edit. by Imevbore, A. M. A., and Adegoke, O. S.) (Ife University Press, in the press).

${ }^{11}$ Bowmaker, A., Optima, 20, 68 (1970).

Here is an example. The subject is asked to underline the word or phrase in the column on the right which he thinks most appropriately completes the row of three terms.

The worm dangling at the end of my fork
invertebrate
(1) useful garden creature
(2) living organism
(3) earth dweller
(4) zoological grouping
(5) snail

In terms of the notation used we have:

\section{Generalizing and Abstracting}

IN theories and experiments on concept formation, the terms generalization and abstraction are often used in an equivocal sense, frequently as synonyms to describe the process of forming a concept from perceptual or verbal data. In one sense, however, the terms are distinct, as for example, when a concept name shifts its meaning from the concrete-general to the abstract-particular, as in the following sentences involving the concept "ballad". (1) A ballad is a piece of creative writing. (2) The ballad is a literary form. We can describe any concept by a double notation, made up of (i) $a_{0}, a_{1}, a_{2} \ldots$ levels of abstraction, where $a_{0}$ is the concrete, and (ii) $g_{0}, g_{1}, g_{11}$, $g_{\text {iii }} \ldots$ degrees of generalization, where $g_{0}$ is the unique or the particular.

In the first sentence the term ballad is used in the concretegeneral sense $\left(a_{0} g_{1}\right)$ although in the second sentence it is used in the abstract-particular sense $\left(a_{1} g_{0}\right)$. The word ballad is thus a homonym in which there is an intimate relationship between its two meanings.

One way of defining the act of abstracting would be as the shift in meaning from the concrete-general to the abstractparticular, as for example $\left(a_{0} g_{\mathrm{i}} \rightarrow a_{1} g_{0}\right)$. Such a shift of meaning is frequently demanded in higher level writing and thinking and the frequency of its usage might indicate advanced cognitive ability.

Table 1 Frequencies of Response

\begin{tabular}{lccccr}
\hline Group & $\mathrm{n}$ & $\begin{array}{c}\text { Abstract- } \\
\text { ing }\end{array}$ & $\begin{array}{c}\text { General- } \\
\text { izing }\end{array}$ & Others & Total \\
$\begin{array}{l}\text { Newly graduated } \\
\quad \text { students }\end{array}$ & 66 & 607 & 834 & 539 & 1,980 \\
$\begin{array}{l}\text { First year students } \\
\text { Fifth year sec. }\end{array}$ & 22 & 149 & 275 & 236 & 660 \\
$\quad$ school & 70 & 389 & 712 & 999 & 2,100 \\
$\begin{array}{l}\text { Third year sec. } \\
\quad \text { school }\end{array}$ & 66 & 221 & 623 & 1,136 & 1,980 \\
$\begin{array}{l}\text { First year sec. } \\
\text { school }\end{array}$ & 63 & 138 & 561 & 1,191 & 1,890 \\
\hline
\end{tabular}

$\mathrm{n}$, Number of people involved.

A psychological test of such a shift can be constructed which makes use of the double meaning of such concept words as ballad, by leading the thinker from the concrete-particular to the concrete-general, and then to ask for a response at a third level, it being assumed that a concrete-general is formed before an abstract-particular. This third level can be tested by a multiple-choice form, incorporating possible responses which individually involve generalization and abstraction, as well as illogical but meaningful alternatives incorporating synonyms, constituent parts and partial associations. particular worm $a_{0} g_{0}$

$\begin{array}{ll}\text { invertebrate } & \text { living organism } \\ a_{0} g_{\mathrm{i}} \longrightarrow & a_{0} g_{\mathrm{ii}} \\ \text { invertebrate } & \text { zoological group } \\ a_{1} g_{0} \longrightarrow a_{1} g_{\mathrm{i}}\end{array}$

If the person tested underlines "living organism", it is assumed he is thinking of invertebrate in the concrete-general sense, but if he chooses "zoological grouping", it is assumed he is using invertebrate in the abstract-particular. The occurrence of other choices gives an indication of illogical connexions.

A test of thirty such items was given to a group of newly graduated students, newly entered first year undergraduates, and fifth, third and first year secondary school pupils. The results are given in Tables 1 and Table 2 (in which the frequencies in 1 are converted to percentages).

\begin{tabular}{lccccc}
\hline \multicolumn{5}{c}{ Table 2 } & \multicolumn{3}{c}{ Percentage Responses } \\
\hline Group & $\mathrm{n}$ & $\begin{array}{c}\text { Abstract- } \\
\text { ing }\end{array}$ & $\begin{array}{c}\text { General- } \\
\text { izing }\end{array}$ & Others & Total \\
$\quad$ Chance & & 20 & 20 & 60 & 100 \\
$\begin{array}{c}\text { Newly graduated } \\
\text { students }\end{array}$ & 66 & 30.7 & 42.1 & 27.2 & 100.0 \\
$\begin{array}{c}\text { First year } \\
\text { students }\end{array}$ & 22 & 22.6 & 41.7 & 35.7 & 100.0 \\
$\begin{array}{c}\text { Fifth year sec. } \\
\text { school }\end{array}$ & 70 & 18.5 & 33.9 & 47.6 & 100.0 \\
$\begin{array}{c}\text { Third year sec. } \\
\text { school }\end{array}$ & 66 & 11.1 & 31.5 & 57.4 & 100.0 \\
$\begin{array}{c}\text { First year sec. } \\
\text { school }\end{array}$ & 63 & 7.3 & 29.7 & 63.0 & 100.0 \\
\hline & & & & & \\
\hline
\end{tabular}

From the percentages (Table 2) it is clear that the capacity to make abstractions in the sense defined here increases steadily through adolescence and into adulthood. The increase in the ability to generalize is less marked. The results seem to confirm that persons involved in higher level learning, such as is carried out at university, develop this capacity to use the abstractparticular form of concepts. Among the graduates, the English honours students made a marginally larger number of abstracting responses. It should be noted that all the secondary school groups made fewer abstracting responses than would be expected by chance.

This method of measuring the capacity to abstract could lead to interesting studies of different groups of adolescents and young adults in different educational and sociological settings.

\section{E. A. PeEL}

Educational Psychology Division,

School of Education,

University of Birmingham 